\title{
Synthesis and Structural Characterization of a Metal Cluster and a Coordination Polymer Based on the $\left[\operatorname{Mn}_{6}\left(\mu_{4}-\mathrm{O}\right)_{2}\right]^{10+}$ Unit
}

\author{
Eleni E. Moushi, Anastasios J. Tasiopoulos, and Manolis J. Manos \\ Department of Chemistry, University of Cyprus, 1678 Nicosia, Cyprus \\ Correspondence should be addressed to Manolis J. Manos, emmanouil.manos@ucy.ac.cy
}

Received 24 February 2010; Accepted 9 March 2010

Academic Editor: Spyros Perlepes

Copyright ( 2010 Eleni E. Moushi et al. This is an open access article distributed under the Creative Commons Attribution License, which permits unrestricted use, distribution, and reproduction in any medium, provided the original work is properly cited.

\begin{abstract}
A new 1-D coordination polymer $\left\{\left[\mathrm{Mn}_{6} \mathrm{O}_{2}\left(\mathrm{O}_{2} \mathrm{CMe}\right)_{10}\left(\mathrm{H}_{2} \mathrm{O}\right)_{4}\right] \cdot 2.5 \mathrm{H}_{2} \mathrm{O}\right\}_{\infty}\left(\mathbf{1} \cdot 2.5 \mathrm{H}_{2} \mathrm{O}\right)_{\infty}$ and the cluster $\left[\mathrm{Mn}_{6} \mathrm{O}_{2}\left(\mathrm{O}_{2}\left(\mathrm{O}_{2} \mathrm{CPh}\right)_{10}\right.\right.$ $\left.(\text { py })_{2}(\mathrm{MeCN})\left(\mathrm{H}_{2} \mathrm{O}\right)\right] \cdot 2 \mathrm{MeCN}(2 \cdot 2 \mathrm{MeCN})$ are reported. Both compounds were synthesized by room temperature reactions of $\left[\mathrm{Mn}_{3}\left(\mu_{3}-\mathrm{O}\right)\left(\mathrm{O}_{2} \mathrm{CR}\right)_{6}(\mathrm{~L})_{2}\left(\mathrm{~L}^{\prime}\right)\right]\left(\mathrm{R}=\mathrm{Me}, \mathrm{L}=\mathrm{L}^{\prime}=\mathrm{py},\left(\mathbf{1} \cdot 2.5 \mathrm{H}_{2} \mathrm{O}\right)_{\infty} ; \mathrm{R}=\mathrm{Ph}, \mathrm{L}=\mathrm{py}, \mathrm{L}^{\prime}=\mathrm{H}_{2} \mathrm{O}, 2 \cdot 2 \mathrm{MeCN}\right)$ in the presence of 3hydroxymethylpyridine $(3 \mathrm{hmpH})$ in acetonitrile. The structures of these complexes are based on hexanuclear mixed-valent manganese carboxylate clusters containing the $\left[\mathrm{Mn}_{4}{ }^{\mathrm{II}} \mathrm{Mn}_{2}{ }^{\mathrm{III}}\left(\mu_{4}-\mathrm{O}\right)_{2}\right]^{10+}$ structural core. $\left(1 \cdot 2.5 \mathrm{H}_{2} \mathrm{O}\right)_{\infty}$ consists of zigzag chain polymers constructed from $\left[\mathrm{Mn}_{6} \mathrm{O}_{2}\left(\mathrm{O}_{2} \mathrm{CMe}\right)_{10}\left(\mathrm{H}_{2} \mathrm{O}\right)_{4}\right]$ repeating units linked through acetate ligands, whereas $2 \cdot 2 \mathrm{MeCN}$ comprises a discrete $\mathrm{Mn}_{6}$-benzoate cluster.
\end{abstract}

\section{Introduction}

The synthesis of Mn clusters has attracted significant interest due to their relevance to many areas including molecular magnetism, catalysis, and bioinorganic chemistry $[1,2]$. In the bioinorganic area, extensive work has been carried out to model the structure and catalytic activity of a tetranuclear Mn cluster, which is present in the water oxidizing centre (WOC) of Photosystem II [3-7]. As a result, a number of oligonuclear high oxidation state Mn-carboxylate clusters have been prepared $[3,5]$, some of which have been studied for their ability to oxidize $\mathrm{H}_{2} \mathrm{O}$ to molecular $\mathrm{O}_{2}[3,6$, 7]. Furthermore, considerable effort has been expended in order to prepare structural and reactivity models of other Mn-containing enzymes, such as Mn catalases. These studies have resulted in a number of oligonuclear $\mathrm{Mn}$ complexes with oxo/alkoxo/hydroxo or carboxylate bridges, some of which have proven to be very efficient catalytic scavengers of $\mathrm{H}_{2} \mathrm{O}_{2}$ [8]. The synthesis of oligonuclear $\mathrm{Mn}$ model compounds often involves preformed Mn carboxylate clusters and coordination polymers as starting materials, with the most popular ones being complexes based on the $\left[\mathrm{Mn}_{3} \mathrm{O}\right]^{6+/ 7+}$ and the $\left[\mathrm{Mn}_{6} \mathrm{O}_{2}\right]^{10+}$ units $[3,9-11]$. Since the various characteristics of the starting materials including their structural core, carboxylate bridges, and terminal ligation have a significant influence on the identity of the reaction product, there is always a need for new additions in the list of known metal precursor compounds.

Herein, we report the syntheses and the crystal structures of the $1 \mathrm{D}$ coordination polymer $\left\{\left[\mathrm{Mn}_{6} \mathrm{O}_{2}\left(\mathrm{O}_{2} \mathrm{CMe}\right)_{10}\left(\mathrm{H}_{2} \mathrm{O}\right)_{4}\right] \cdot 2.5 \mathrm{H}_{2} \mathrm{O}\right\}_{\infty}\left(1 \cdot 2.5 \mathrm{H}_{2} \mathrm{O}\right)_{\infty}$ and the discrete cluster $\left[\mathrm{Mn}_{6} \mathrm{O}_{2}\left(\mathrm{O}_{2} \mathrm{CPh}\right)_{10}(\mathrm{py})_{2}(\mathrm{MeCN})\left(\mathrm{H}_{2} \mathrm{O}\right)\right]$ - $2 \mathrm{MeCN}(\mathbf{2} \cdot 2 \mathrm{MeCN})$, which both contain the $\left[\mathrm{Mn}_{4}{ }^{\mathrm{II}} \mathrm{Mn}_{2}{ }^{\mathrm{III}}\left(\mu_{4}-\mathrm{O}\right)_{2}\right]^{10+}$ structural core. Compound $2 \cdot 2 \mathrm{MeCN}$ is a new addition in the family of structurallycharacterized $\mathrm{Mn}_{6}$-benzoate clusters [12, 13], whereas $\left(\mathbf{1} \cdot 2.5 \mathrm{H}_{2} \mathrm{O}\right)_{\infty}$ represents one of the few coordination polymers based on hexanuclear Mn clusters [14-17].

\section{Experimental}

2.1. Materials. All manipulations were performed under aerobic conditions using materials (reagent grade) and solvents as received; water was distilled in-house. $\left[\mathrm{Mn}_{3} \mathrm{O}\left(\mathrm{O}_{2} \mathrm{CMe}\right)_{6}(\mathrm{py})_{3}\right]$. py and $\left[\mathrm{Mn}_{3} \mathrm{O}\left(\mathrm{O}_{2} \mathrm{CPh}\right)_{6}(\mathrm{py})_{2}\left(\mathrm{H}_{2} \mathrm{O}\right)\right]$ $\cdot 0.5 \mathrm{CH}_{3} \mathrm{CN}$ were prepared as described elsewhere [18]. 
2.2. Compound Preparation. $\left\{\left[\mathrm{Mn}_{6} \mathrm{O}_{2}\left(\mathrm{O}_{2} \mathrm{CMe}\right)_{10} \cdot\left(\mathrm{H}_{2} \mathrm{O}\right)_{4}\right]\right.$ $\left.\cdot 2.5 \mathrm{H}_{2} \mathrm{O}\right\}_{\infty}\left(\mathbf{1} \cdot 2.5 \mathrm{H}_{2} \mathrm{O}\right)_{\infty}:\left[\mathrm{Mn}_{3} \mathrm{O}\left(\mathrm{O}_{2} \mathrm{CMe}\right)_{6}(\mathrm{py})_{3}\right] \cdot$ py $(0.2 \mathrm{~g}$, $0.24 \mathrm{mmol})$ was dissolved in $\mathrm{MeCN}(10 \mathrm{~mL})$, and then $3 \mathrm{hmpH}(0.05 \mathrm{~g}, 0.46 \mathrm{mmol})$ was added to the dark brown solution. The resulting red-brown solution was left under magnetic stirring for $\sim 50$ minutes, filtered off, and the filtrate was left undisturbed at room temperature. After a few weeks, brown crystals of $\left(\mathbf{1} \cdot 2.5 \mathrm{H}_{2} \mathrm{O}\right)_{\infty}$ suitable for X-ray crystallography were formed. The crystals were collected by filtration, washed with $\mathrm{MeCN}(10 \mathrm{~mL})$, and $\mathrm{Et}_{2} \mathrm{O}(2 \times 10 \mathrm{~mL})$ and dried in vacuo. The yield was $\sim 27 \%$ based on total Mn content. Anal. Calc. for $\mathrm{C}_{20} \mathrm{H}_{43} \mathrm{Mn}_{6} \mathrm{O}_{28.5}\left(\mathbf{1} \cdot 2.5 \mathrm{H}_{2} \mathrm{O}\right)_{\infty}$ : C, 22.47; H, 4.05. Found: $\mathrm{C}$ 22.29; H 4.25\%. IR data $\left(\mathrm{KBr}\right.$ pellet, $\left.\mathrm{cm}^{-1}\right): \widetilde{v}=3404(\mathrm{~m}, \mathrm{br})$, $1582(\mathrm{~s}), 1421(\mathrm{~s}), 1371(\mathrm{w}), 1028(\mathrm{~m}), 667$ (s), $619(\mathrm{~s})$.

$\left[\mathrm{Mn}_{6} \mathrm{O}_{2}\left(\mathrm{O}_{2} \mathrm{CPh}\right)_{10}(\mathrm{py})_{2}(\mathrm{MeCN})\left(\mathrm{H}_{2} \mathrm{O}\right)\right] \cdot 2 \mathrm{MeCN}$ (2.2MeCN): $\quad\left[\mathrm{Mn}_{3} \mathrm{O}\left(\mathrm{O}_{2} \mathrm{CPh}\right)_{6}(\mathrm{py})_{2}\left(\mathrm{H}_{2} \mathrm{O}\right)\right] \cdot 0.5 \mathrm{CH}_{3} \mathrm{CN}$ $(0.27 \mathrm{~g}, 0.24 \mathrm{mmol})$ was dissolved in $\mathrm{MeCN}(10 \mathrm{~mL})$ and then, $3 \mathrm{hmpH}(0.05 \mathrm{~g}, 0.46 \mathrm{mmol})$ was added to the dark brown solution. The resulting red-brown solution was left under magnetic stirring for $\sim 45$ minutes, filtered off and the filtrate was left undisturbed at room temperature. After a few weeks, brown crystals of $(2 \cdot 2 \mathrm{MeCN})$ suitable for X-ray crystallography were formed. The crystals were collected by filtration, washed with $\mathrm{MeCN}(10 \mathrm{~mL})$ and $\mathrm{Et}_{2} \mathrm{O}(2 \times 10 \mathrm{~mL})$ and dried in vacuo. The yield was $\sim 20 \%$ based on total $\mathrm{Mn}$ content. Anal. Calc. for $\mathrm{C}_{86} \mathrm{H}_{71} \mathrm{Mn}_{6} \mathrm{~N}_{5} \mathrm{O}_{23}(2 \cdot 2 \mathrm{MeCN})$ : C, 55.17; H, 3.82; N, 3.74. Found: C 54.98; H 3.91; N, 3.53\%. IR data $\left(\mathrm{KBr}\right.$ pellet, $\left.\mathrm{cm}^{-1}\right): \widetilde{v}=3398(\mathrm{~m}, \mathrm{br}), 1607(\mathrm{~s}), 1570$ (s), $1430(\mathrm{~s}) 720(\mathrm{~s}), 691$ (m), $676(\mathrm{~m}), 614(\mathrm{~m})$.

2.3. X-Ray Crystallography. Data were collected on an Oxford-Diffraction Xcalibur diffractometer, equipped with a CCD area detector and a graphite monochromator utilizing Mo-K $\alpha$ radiation $(\lambda=0.71073 \AA)$. Suitable crystals were attached to glass fibers using paratone- $\mathrm{N}$ oil and transferred to a goniostat where they were cooled for data collection. Unit cell dimensions were determined and refined by using $4714\left(3.14 \leq \theta \leq 30.42^{\circ}\right)$ and $23078(3.07 \leq \theta \leq$ $\left.31.25^{\circ}\right)$ reflections for $\left(\mathbf{1} \cdot 2.5 \mathrm{H}_{2} \mathrm{O}\right)_{\infty}$ and $\mathbf{2} \cdot 2 \mathrm{MeCN}$, respectively. Empirical absorption corrections (multiscan based on symmetry-related measurements) were applied using CrysAlis RED software [19]. The structures were solved by direct methods using SIR92 [20] and refined on $F^{2}$ using full-matrix least squares with SHELXL97 [21]. Software packages used: CrysAlis CCD [19] for data collection, CrysAlis RED [19] for cell refinement and data reduction, WINGX for geometric calculations [22], and DIAMOND [23] and MERCURY [24] for molecular graphics. The non$\mathrm{H}$ atoms were treated anisotropically, whereas the aromatic and methyl-hydrogen atoms were placed in calculated, ideal positions and refined as riding on their respective carbon atoms. The $\mathrm{H}$ atoms of water molecules could not be located. Unit cell data and structure refinement details are listed in Table 1.

2.4. Physical Measurements. Elemental analyses (C, H, N) were performed by the in-house facilities of the University of Cyprus, Chemistry Department. IR spectra were recorded
TABLe 1: Crystallographic data for complexes $\left(\mathbf{1} \cdot 2.5 \mathrm{H}_{2} \mathrm{O}\right)_{\infty}$ and $(2 \cdot 2 \mathrm{MeCN})$.

\begin{tabular}{lcc}
\hline & 1 & 2 \\
\hline Formula $^{\mathrm{a}}$ & $\mathrm{C}_{40} \mathrm{H}_{86} \mathrm{Mn}_{12} \mathrm{O}_{57}$ & $\mathrm{C}_{86} \mathrm{H}_{71} \mathrm{Mn}_{6} \mathrm{~N}_{5} \mathrm{O}_{23}$ \\
$M_{w}$ & 2138.33 & 1872.13 \\
Crystal System & Orthorhombic & Triclinic \\
Space group & $\mathrm{P} \mathrm{b} \mathrm{c} \mathrm{a}$ & $\mathrm{P} \overline{1}$ \\
$a / \AA$ & $13.615(2)$ & $14.4690(8)$ \\
$b / \AA$ & $21.274(3)$ & $15.8172(7)$ \\
$c / \AA$ & $30.459(4)$ & $18.636(2)$ \\
$\alpha /{ }^{\mathrm{o}}$ & 90 & $83.861(4)$ \\
$\beta /{ }^{\mathrm{o}}$ & 90 & $86.750(4)$ \\
$\gamma /{ }^{\mathrm{o}}$ & 90 & $83.463(4)$ \\
$V / \AA^{3}$ & $8822(2)$ & $4208.8(4)$ \\
$Z$ & 4 & 2 \\
$T / \mathrm{K}$ & $100(2)$ & $100(2)$ \\
$\lambda^{\mathrm{b}}, \AA$ & 0.71073 & 0.71073 \\
$D_{c}, \mathrm{~g} / \mathrm{cm}^{-3} \mathrm{a}$ & 1.610 & 1.477 \\
$\mu\left(\mathrm{Mo}-\mathrm{K}^{2} \alpha\right) / \mathrm{mm}^{-1}$ & 1.750 & 0.950
\end{tabular}

Reflections

collected/unique $\left(R_{\text {int }}\right)$ 38727/7727(0.1214) 46797/11574(0.0493)

Obs. refl. [I $>2 \sigma(\mathrm{I})] . \quad 3263 \quad 8550$

$R 1 \%^{\mathrm{c}} \quad 0.0474 \quad 0.0656$

$w R 2^{\mathrm{d}} \quad 0.0931 \quad 0.1608$

Goodness of fit on $F^{2} \quad 0.807 \quad 0.974$

$\Delta \rho \mathrm{max} / \mathrm{min} / \mathrm{e} \AA^{-3} \quad 0.891 /-0.409 \quad 1.434 /-1.333$

${ }^{\mathrm{a}}$ Including solvent molecules and all hydrogen atoms (even the $\mathrm{H}$ atoms of $\left.\mathrm{H}_{2} \mathrm{O}\right) .{ }^{\mathrm{b}}$ Graphite monochromator. ${ }^{\mathrm{c}} R 1=\Sigma\left|F_{\mathrm{o}}\right|-\left|F_{c}\right| / \Sigma\left|F_{\mathrm{o}}\right| .{ }^{\mathrm{d}} w R 2=$ $\left.\left[\Sigma\left[w\left(F_{o}^{2}-F_{c}^{2}\right)^{2}\right] / \Sigma\left[w F_{o}^{2}\right)^{2}\right]\right]^{1 / 2}, w=1 /\left[\sigma 2\left(F_{o}^{2}\right)+(m \cdot p)^{2}+n \cdot p\right], p=$ $\left[\max \left(F_{o}^{2}, 0\right)+2 F_{c}^{2}\right] / 3$, and $m$ and $n$ are constants.

on $\mathrm{KBr}$ pellets in the $4000-400 \mathrm{~cm}^{-1}$ range using a Shimadzu Prestige-21 spectrometer.

\section{Results and Discussion}

3.1. Syntheses. The goal of the described research is the synthesis of multidimensional coordination polymers composed of polynuclear Mn carboxylate clusters with the use of hydroxymethyl-pyridine derivatives [e.g., 4-hydroxymethyl-pyridine (4hmpH), 3-hydroxymethylpyridine $(3 \mathrm{hmpH})$ ] as bridging ligands. The initial result from these investigations was a new hexanuclear $\mathrm{Mn}$ complex $\left[\mathrm{Mn}_{6} \mathrm{O}_{2}\left(\mathrm{O}_{2} \mathrm{CPh}\right)_{10}(4 \mathrm{hmpH})_{3}(\mathrm{MeCN})\right]$, which contains the $\left[\mathrm{Mn}_{6} \mathrm{O}_{2}\right]^{10+}$ structural core and terminal $4 \mathrm{hmpH}$ ligands [12]. This compound was prepared from a reaction of $\left[\mathrm{Mn}\left(\mathrm{O}_{2} \mathrm{CPh}\right)_{2}\right] \cdot 2 \mathrm{H}_{2} \mathrm{O}$ with $4 \mathrm{hmpH}$ in $\mathrm{MeCN}$. Various modifications of this reaction system that were performed involved the use of preformed Mn clusters as precursor compounds together with $3 \mathrm{hmpH}$. Thus, the reaction of $\left[\mathrm{Mn}_{3}\left(\mu_{3}-\mathrm{O}\right)\left(\mathrm{O}_{2} \mathrm{CR}\right)_{6}(\mathrm{~L})_{2}\left(\mathrm{~L}^{\prime}\right)\right]\left(\mathrm{R}=\mathrm{Me}, \mathrm{L}=\mathrm{L}^{\prime}\right.$ = py, $\left(\mathbf{1} \cdot 2.5 \mathrm{H}_{2} \mathrm{O}\right)_{\infty} ; \mathrm{R}=\mathrm{Ph}, \mathrm{L}=$ py, $\left.\mathrm{L}^{\prime}=\mathrm{H}_{2} \mathrm{O}, 2 \cdot 2 \mathrm{MeCN}\right)$ with $3 \mathrm{hmpH}$ in acetonitrile resulted in the isolation of compounds $\left(\mathbf{1} \cdot 2.5 \mathrm{H}_{2} \mathrm{O}\right)_{\infty}$ and $\mathbf{2} \cdot 2 \mathrm{MeCN}$, which however 
did not contain the $3 \mathrm{hmpH}$ ligands. The formation of $(\mathbf{1})_{\infty}$ and $\mathbf{2}$ is summarized in equations 1 and 2, respectively:

$$
\begin{aligned}
2 \mathrm{n} & {\left[\mathrm{Mn}_{3} \mathrm{O}\left(\mathrm{O}_{2} \mathrm{CMe}\right)_{6}(\mathrm{py})_{3}\right]+4 \mathrm{nH}_{2} \mathrm{O}+2 \mathrm{ne}^{-} } \\
& \longrightarrow\left[\mathrm{Mn}_{6} \mathrm{O}_{2}\left(\mathrm{O}_{2} \mathrm{CMe}\right)_{10}\left(\mathrm{H}_{2} \mathrm{O}\right)_{4}\right]_{\mathrm{n}}+2 \mathrm{nMeCO}_{2}{ }^{-}+6 \mathrm{npy}
\end{aligned}
$$

$$
\begin{aligned}
2\left[\mathrm{Mn}_{3} \mathrm{O}\left(\mathrm{O}_{2} \mathrm{CPh}\right)_{6}(\mathrm{py})_{2}\left(\mathrm{H}_{2} \mathrm{O}\right)\right]+\mathrm{MeCN}+2 \mathrm{e}^{-} \\
\longrightarrow\left[\mathrm{Mn}_{6} \mathrm{O}_{2}\left(\mathrm{O}_{2} \mathrm{CPh}\right)_{10}(\mathrm{py})_{2}(\mathrm{MeCN})\left(\mathrm{H}_{2} \mathrm{O}\right)\right] \\
+2 \mathrm{PhCO}_{2}{ }^{-}+2 \mathrm{py}+\mathrm{H}_{2} \mathrm{O}
\end{aligned}
$$

As it will be discussed in detail below, the structures of $\left(\mathbf{1} \cdot 2.5 \mathrm{H}_{2} \mathrm{O}\right)_{\infty}$ and $\mathbf{2} \cdot 2 \mathrm{MeCN}$ are very similar with one major difference between them being the fact that $\left(1 \cdot 2.5 \mathrm{H}_{2} \mathrm{O}\right)_{\infty}$ is a coordination polymer, whereas $2 \cdot 2 \mathrm{MeCN}$ is a discrete metal cluster. A possible explanation for this is that the bulky $\mathrm{PhCO}_{2}{ }^{-}$groups that are present in $2 \cdot 2 \mathrm{MeCN}$ prevent the polymerization of the $\mathrm{Mn}_{6}$ clusters, whereas in $\left(\mathbf{1} \cdot 2.5 \mathrm{H}_{2} \mathrm{O}\right)_{\infty}$ there are only acetate ligands that are more flexible and thus can easily bridge $\mathrm{Mn}_{6}$ units leading to a polymeric species. We also note that the average oxidation state of the final products (2.33) of the two reactions is lower than that of the starting materials (2.66). Such a reduction could be explained assuming that a disproportionation reaction of the $\mathrm{Mn}_{3}$ starting materials takes place upon their dissolution in $\mathrm{MeCN}$ in the presence of $3 \mathrm{hmpH}$. Then, the reduced species are aggregated to form $\left(1 \cdot 2.5 \mathrm{H}_{2} \mathrm{O}\right)_{\infty}$ or $2 \cdot 2 \mathrm{MeCN}$ and the products with $\mathrm{Mn}$ ions in higher oxidation states remain in the solution. Similar reactions as those leading to the isolation of $\left(\mathbf{1} \cdot 2.5 \mathrm{H}_{2} \mathrm{O}\right)_{\infty}$ or $\mathbf{2} \cdot 2 \mathrm{MeCN}$ were performed using $4 \mathrm{hmpH}$ or pyridine instead of $3 \mathrm{hmpH}$ in the reaction mixtures. These reactions resulted in the isolation of microcrystalline products that have not been completely characterized so far, but seem to be different than compounds $\left(\mathbf{1} \cdot 2.5 \mathrm{H}_{2} \mathrm{O}\right)_{\infty}$ and $\mathbf{2} \cdot 2 \mathrm{MeCN}$ (by comparisons of infrared spectra). Reactions were also carried out by us in the past, where no other reagent (e.g., pyridine or triethylamine) was used besides the $\left[\mathrm{Mn}_{3} \mathrm{O}\left(\mathrm{O}_{2} \mathrm{CMe}\right)_{6}(\mathrm{py})_{3}\right]$ precursor compound and the solvent. In that case, an $1 \mathrm{D}$ coordination polymer based on $\mathrm{Mn}_{3}$-carboxylate cluster linked by $\mathrm{Mn}^{2+}$ ions was isolated [25]. Therefore, $3 \mathrm{hmpH}$ seems to play an important role in the formation of compounds $\left(1 \cdot 2.5 \mathrm{H}_{2} \mathrm{O}\right)_{\infty}$ and $2 \cdot 2 \mathrm{MeCN}$, since different compounds are isolated in the absence of $3 \mathrm{hmpH}$. However, the exact role of $3 \mathrm{hmpH}$ in the assembly of these compounds is yet unidentified.

3.2. Crystal Structures. The structure of the repeating unit of $\left(\mathbf{1} \cdot 2.5 \mathrm{H}_{2} \mathrm{O}\right)_{\infty}$ is very similar to that of compound $2 \cdot 2 \mathrm{MeCN}$ (with the main differences between the two compounds being the terminal ligation and the type of carboxylate ligands) and thus, only the first one will be discussed in detail. Selected interatomic distances for $\left(\mathbf{1} \cdot 2.5 \mathrm{H}_{2} \mathrm{O}\right)_{\infty}$ and $2 \cdot 2 \mathrm{MeCN}$ are given in Tables 2 and 3 , respectively.

Compound $\left(\mathbf{1} \cdot 2.5 \mathrm{H}_{2} \mathrm{O}\right)_{\infty}$ crystallizes in the orthorhombic space group $\mathrm{Pbca}$. Its repeating unit comprises the
Table 2: Selected interatomic distances $(\AA)$ for complex

\begin{tabular}{|c|c|c|c|}
\hline \multicolumn{4}{|c|}{ Bond Distances $(\AA)$} \\
\hline $\mathrm{Mn} 1 \cdots \operatorname{Mn} 2$ & $3.133(2)$ & $\mathrm{Mn} 3-\mathrm{O} 22$ & $2.206(3)$ \\
\hline $\mathrm{Mn} 2 \cdots \mathrm{Mn} 6$ & $2.8134(9)$ & Mn3-N1 & $2.263(4)$ \\
\hline $\operatorname{Mn} 2 \cdots \operatorname{Mn} 5$ & $3.130(2)$ & Mn3-O12 & $2.317(3)$ \\
\hline $\mathrm{Mn} 3 \cdots \operatorname{Mn} 6$ & $3.162(2)$ & Mn4-O6 & $2.124(3)$ \\
\hline Mn4 $\cdots$ Mn6 & $3.167(2)$ & $\mathrm{Mn} 4-\mathrm{O} 20$ & $2.131(3)$ \\
\hline Mn1-O1 & $2.121(3)$ & Mn4-O9 & $2.154(3)$ \\
\hline Mn1-O7 & $2.121(3)$ & Mn4-O23 & $2.186(3)$ \\
\hline Mn1-O3 & $2.145(3)$ & $\mathrm{Mn} 4-\mathrm{N} 2$ & $2.287(4)$ \\
\hline $\mathrm{Mn} 1-\mathrm{O} 22$ & $2.190(3)$ & $\mathrm{Mn} 4-\mathrm{O} 8$ & $2.302(3)$ \\
\hline $\mathrm{Mn} 1-\mathrm{N} 3$ & $2.250(5)$ & Mn5-O19 & $2.155(3)$ \\
\hline Mn1-O5 & $2.281(3)$ & Mn5-O18 & $2.158(3)$ \\
\hline $\mathrm{Mn} 2-\mathrm{O} 22$ & $1.872(3)$ & $\mathrm{Mn} 5-\mathrm{O} 23$ & $2.176(3)$ \\
\hline $\mathrm{Mn} 2-\mathrm{O} 23$ & $1.894(3)$ & Mn5-O11 & $2.197(3)$ \\
\hline $\mathrm{Mn} 2-\mathrm{O} 17$ & $1.936(3)$ & Mn5-O21 & $2.226(3)$ \\
\hline Mn2-O4 & $1.972(4)$ & Mn5-O14 & $2.237(4)$ \\
\hline $\mathrm{Mn} 2-\mathrm{O} 5$ & $2.239(3)$ & Mn6-O22 & $1.889(3)$ \\
\hline $\mathrm{Mn} 2-\mathrm{O} 14$ & $2.241(3)$ & $\mathrm{Mn6-O} 23$ & $1.893(3)$ \\
\hline $\mathrm{Mn} 3-\mathrm{O} 2$ & $2.127(4)$ & Mn6-O10 & $1.951(4)$ \\
\hline $\mathrm{Mn3}-\mathrm{O} 13$ & $2.146(3)$ & Mn6-O16 & $1.954(3)$ \\
\hline \multirow[t]{2}{*}{ Mn3-O15 } & $2.151(3)$ & Mn6-O12 & $2.202(3)$ \\
\hline & & Mn6-O8 & $2.232(3)$ \\
\hline
\end{tabular}
$\left(1 \cdot 2.5 \mathrm{H}_{2} \mathrm{O}\right)_{\infty}$.

\begin{tabular}{lccl}
\hline \multicolumn{4}{c}{ Bond distances $(\AA)$} \\
\hline Mn1 $\cdots$ Mn2 & $3.138(2)$ & Mn3-O26 & $2.186(4)$ \\
Mn2 $\cdots$ Mn6 & $2.798(2)$ & Mn3-O24 & $2.195(4)$ \\
Mn2 $\cdots$ Mn5 & $3.164(2)$ & Mn3-O12 & $2.201(4)$ \\
Mn3 $\cdots$ Mn6 & $3.131(2)$ & Mn4-O19 & $2.138(5)$ \\
Mn4 $\cdots$ Mn6 & $3.187(2)$ & Mn4-O22 & $2.160(5)$ \\
Mn1-O7 & $2.130(5)$ & Mn4-O6 & $2.173(5)$ \\
Mn1-O24 & $2.162(4)$ & Mn4-O9 & $2.191(5)$ \\
Mn1-O3 & $2.164(5)$ & Mn4-O25 & $2.240(4)$ \\
Mn1-O21 & $2.172(4)$ & Mn4-O8 & $2.313(5)$ \\
Mn1-O1 & $2.176(4)$ & Mn5-O20 & $2.125(5)$ \\
Mn1-O5 & $2.293(5)$ & Mn5-O11 & $2.142(5)$ \\
Mn2-O25 & $1.883(4)$ & Mn5-O18 & $2.193(5)$ \\
Mn2-O24 & $1.891(4)$ & Mn5-O14 & $2.193(4)$ \\
Mn2-O4 & $1.943(4)$ & Mn5-O23 & $2.207(4)$ \\
Mn2-O17 & $1.962(5)$ & Mn5-O25 & $2.265(4)$ \\
Mn2-O5 & $2.229(4)$ & Mn6-O24 & $1.892(4)$ \\
Mn2-O14 & $2.257(4)$ & Mn6-O25 & $1.894(5)$ \\
Mn3-O2 & $2.143(4)$ & Mn6-O10 & $1.931(4)$ \\
Mn3-O15 & $2.155(5)$ & Mn6-O16 & $1.973(5)$ \\
Mn3-O13 & $2.163(5)$ & Mn6-O8 & $2.202(4)$ \\
& & Mn6-O12 & $2.232(4)$ \\
\hline
\end{tabular}

TABLE 3: Selected interatomic distances ( $\AA$ ) for complex $(2 \cdot 2 \mathrm{MeCN})$.

hexanuclear cluster $\left[\mathrm{Mn}_{6} \mathrm{O}_{2}\left(\mathrm{O}_{2} \mathrm{CMe}\right)_{10}\left(\mathrm{H}_{2} \mathrm{O}\right)_{4}\right]$ (Figure 1) and totally $2.5 \mathrm{H}_{2} \mathrm{O}$ molecules of crystallization. Charge 
TABLE 4: Bond valence sum (BVS) $)^{\mathrm{a}, \mathrm{b}}$ calculations for complexes $\left(\mathbf{1} \cdot 2.5 \mathrm{H}_{2} \mathrm{O}\right)_{\infty}$ and $(\mathbf{2} \cdot 2 \mathrm{MeCN})$

\begin{tabular}{lcccccc}
\hline & \multicolumn{3}{c}{ Complex 1 } & \multicolumn{3}{c}{ Complex 2 } \\
& $\mathrm{Mn}^{\mathrm{II}}$ & $\mathrm{Mn}^{\mathrm{III}}$ & $\mathrm{Mn}^{\mathrm{IV}}$ & $\mathrm{Mn}^{\mathrm{II}}$ & $\mathrm{Mn}^{\mathrm{III}}$ & $\mathrm{Mn}^{\mathrm{IV}}$ \\
\hline Mn1 & $\mathbf{1 . 9 6}$ & 1.79 & 1.88 & $\mathbf{2 . 0 3}$ & 1.87 & 1.94 \\
Mn2 & 3.20 & $\mathbf{2 . 9 2}$ & 3.07 & 3.21 & $\mathbf{2 . 9 4}$ & 3.08 \\
Mn3 & $\mathbf{1 . 9 9}$ & 1.82 & 1.91 & $\mathbf{1 . 9 4}$ & 1.79 & 1.85 \\
Mn4 & $\mathbf{1 . 8 6}$ & 1.70 & 1.79 & $\mathbf{1 . 9 6}$ & 1.81 & 1.87 \\
Mn5 & $\mathbf{1 . 9 3}$ & 1.76 & 1.85 & $\mathbf{1 . 9 0}$ & 1.74 & 1.83 \\
Mn6 & 3.21 & $\mathbf{2 . 9 4}$ & 3.09 & 3.22 & $\mathbf{2 . 9 4}$ & 3.09 \\
\hline
\end{tabular}

${ }^{\mathrm{a}}$ The bold value is the one closest to the charge for which it was calculated.

${ }^{\mathrm{b}}$ The oxidation state is the nearest whole number to the bold value.

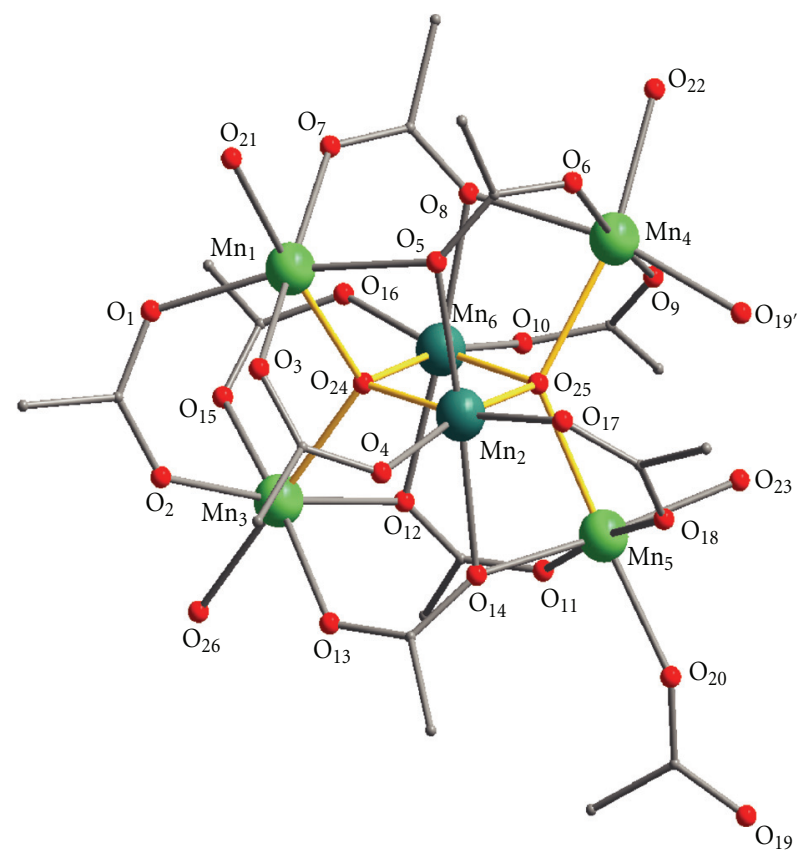

Figure 1: A partially labeled plot of the repeating unit of $(\mathbf{1})_{\infty}$. The yellow lines emphasize the $\left[\mathrm{Mn}_{4}{ }^{\mathrm{II}} \mathrm{Mn}_{2}{ }^{\mathrm{III}}\left(\mu_{4}-\mathrm{O}\right)_{2}\right]^{10+}$ core. Color code: $\mathrm{Mn}^{\mathrm{II}}$, green; $\mathrm{Mn}^{\mathrm{III}}$, dark green; $\mathrm{O}$, red; $\mathrm{C}$, grey. $\mathrm{H}$ atoms are omitted for clarity.

considerations, bond valence sum calculations (Table 4) and inspection of metric parameters indicate that the cluster is mixed-valent containing four $\mathrm{Mn}^{\mathrm{II}}$ and two $\mathrm{Mn}^{\mathrm{III}}$ ions. The $\left[\mathrm{Mn}_{4}{ }^{\mathrm{II}} \mathrm{Mn}_{2}{ }^{\mathrm{III}}\left(\mu_{4}-\mathrm{O}\right)_{2}\right]^{10+}$ core of $\mathbf{1}$ has appeared several times in the literature as will be discussed in detail below and can be described as consisting of two edge-sharing $\left(\mu_{4}-\mathrm{O}\right) \mathrm{Mn}_{4}$ tetrahedra. Such units are defined as anti-T1 tetrahedra (T1 is a structural unit having a cation at the center and four anions at the apices of the tetrahedron) [26]. The common edge of the two anti-T1 tetrahedra is formed by the two $\mathrm{Mn}^{\text {III }}$ ions, whereas the four $\mathrm{Mn}^{\text {II }}$ ions occupy the corners of the $\left[\mathrm{Mn}_{4}{ }^{\mathrm{II}} \mathrm{Mn}_{2}{ }^{\mathrm{III}}\left(\mu_{4}-\mathrm{O}\right)_{2}\right]^{10+}$ core. The peripheral ligation of the $\mathrm{Mn}$ atoms is completed by 4 terminal $\mathrm{H}_{2} \mathrm{O}$ molecules (ligated to the four $\mathrm{Mn}^{\mathrm{II}}$ atoms) and 10 acetate ligands.

All $\mathrm{Mn}$ atoms are in distorted octahedral geometries. Five of the intra-cluster acetate groups are $\mu_{2}$ with each of their carboxylate oxygen atoms acting as terminal ligand for a Mn center. Four acetate ligands are coordinated in $\eta^{1}: \eta^{2}: \mu_{3}$ fashion. The remaining carboxylate ligand bridges two $\mathrm{Mn}^{\mathrm{II}}$ atoms $(\mathrm{Mn} \cdots$ Mn distance $=4.7914(2) \AA)$ of adjacent $\mathrm{Mn}_{6}$ clusters, thus resulting in the formation of a zigzag chain structure (Figure 2). The chains are interacting through hydrogen bonds $(\mathrm{O} \cdots \mathrm{O}$ distances $2.7-2.9 \AA)$ involving the coordinated water molecules and carboxylate $\mathrm{O}$ atoms. Thus, a two-dimensional hydrogen-bonded polymer with a 4-connected topology is formed (Figure 3). The hydrogen bonds involving the lattice water molecules cannot be identified with accuracy due to the positional disorder of these molecules and thus, are not discussed here.

A representation of the structure of $2 \cdot 2 \mathrm{MeCN}$ is given in Figure 4 . The structure of $2 \cdot 2 \mathrm{MeCN}$ is very similar to that of $\left(\mathbf{1} \cdot 2.5 \mathrm{H}_{2} \mathrm{O}\right)_{\infty}$ with the main differences between them being (i) the type of terminal ligands $\left[4 \mathrm{H}_{2} \mathrm{O}\right.$ for $\left(1 \cdot 2.5 \mathrm{H}_{2} \mathrm{O}\right)_{\infty} ; 2$ py, one $\mathrm{MeCN}$ and one $\mathrm{H}_{2} \mathrm{O}$ for $2 \cdot 2 \mathrm{MeCN}$ ] (ii) the type of carboxylate groups (acetate for $\left(\mathbf{1} \cdot 2.5 \mathrm{H}_{2} \mathrm{O}\right)_{\infty}$; benzoate for $2 \cdot 2 \mathrm{MeCN})$ and (iii) their dimensionality $\left[\left(1 \cdot 2.5 \mathrm{H}_{2} \mathrm{O}\right)_{\infty}\right.$ is a coordination polymer, whereas $2 \cdot 2 \mathrm{MeCN}$ is a discrete metal cluster]. Regarding point (iii) we note that examination of the packing of $2 \cdot 2 \mathrm{MeCN}$ revealed the existence of intermolecular hydrogen bonding interactions $(\mathrm{O} \cdots \mathrm{O}$ distances 2.792(4) and 2.809(4) $\AA$ ) involving the terminal $\mathrm{H}_{2} \mathrm{O}$ molecule and two $\mathrm{O}_{\text {benzoate }}$ atoms of two neighboring $\mathrm{Mn}_{6}$ molecules resulting in the formation of a dimeric $(2 \cdot 2 \mathrm{MeCN})_{2}$ aggregate.

The $\mathrm{Mn}_{6}$ unit that appears in $\left(\mathbf{1} \cdot 2.5 \mathrm{H}_{2} \mathrm{O}\right)_{\infty}$ and $2 \cdot 2 \mathrm{MeCN}$, that is, the cluster $\left[\mathrm{Mn}_{6} \mathrm{O}_{2}\left(\mathrm{O}_{2} \mathrm{CR}\right)_{10}(\mathrm{~L})_{2}\left(\mathrm{~L}^{\prime}\right)\right.$ $\left.\left(\mathrm{L}^{\prime \prime}\right)\right]\left(\mathrm{R}=\mathrm{Me}, \mathrm{L}=\mathrm{L}^{\prime}=\mathrm{L}^{\prime \prime}=\mathrm{H}_{2} \mathrm{O}, \mathbf{1} ; \mathrm{R}=\mathrm{Ph}, \mathrm{L}=\mathrm{py}, \mathrm{L}^{\prime}\right.$ $\left.=\mathrm{H}_{2} \mathrm{O}, \mathrm{L}^{\prime \prime}=\mathrm{MeCN}, 2\right)$, has a structural motif found in several hexanuclear Mn clusters and coordination polymers $[9,12-16]$. For example, we have recently reported the discrete cluster $\left[\mathrm{Mn}_{6} \mathrm{O}_{2}\left(\mathrm{O}_{2} \mathrm{CPh}\right)_{10}(4 \mathrm{hmpH})_{3}(\mathrm{MeCN})\right]$ containing the $\left[\mathrm{Mn}_{4}{ }^{\mathrm{II}} \mathrm{Mn}_{2}{ }^{\mathrm{III}}\left(\mu_{4}-\mathrm{O}\right)_{2}\right]^{10+}$ core and also three terminal $4 \mathrm{hmpH}$ groups linked through their $\mathrm{N}_{\text {pyridine }}$ atom and a MeCN molecule [12]. In addition, compound $\left(\mathbf{1} \cdot 2.5 \mathrm{H}_{2} \mathrm{O}\right)_{\infty}$ is closely related to compound $\left\{\left[\mathrm{Mn}_{6} \mathrm{O}_{2}\left(\mathrm{O}_{2} \mathrm{CEt}\right)_{10}\left(\mathrm{H}_{2} \mathrm{O}\right)_{4}\right] \cdot 2 \mathrm{EtCO}_{2} \mathrm{H}\right\}_{\infty} \quad\left(3 \cdot 2 \mathrm{EtCO}_{2} \mathrm{H}\right)_{\infty}$, recently published [14]. The main structural differences between them lie in the type of carboxylate ligands in these compounds, being acetate groups in $\left(1 \cdot 2.5 \mathrm{H}_{2} \mathrm{O}\right)_{\infty}$ and propionate ligands in $\left(3 \cdot 2 \mathrm{EtCO}_{2} \mathrm{H}\right)_{\infty}$ and also in the type of the crystallization solvent molecules. Other related examples to $\left(\mathbf{1} \cdot 2.5 \mathrm{H}_{2} \mathrm{O}\right)_{\infty}$ comprise the chain polymers $\left[\mathrm{Mn}_{6} \mathrm{O}_{2}\left(\mathrm{O}_{2} \mathrm{CCMe}_{3}\right)_{10}(\text { thf })_{2}\right.$ (NIT-Me) $\left[\mathrm{Mn}_{6} \mathrm{O}_{2}\left(\mathrm{O}_{2} \mathrm{CCMe}_{3}\right)_{10}\right.$ (thf) $\left.\left(\mathrm{CH}_{2} \mathrm{Cl}_{2}\right)(\mathrm{NIT}-\mathrm{Me})\right]($ thf $=$ tetrahydrofuran, NIT-Me $=4$,5-dihydro- $1 \mathrm{H}$ - imidazolyl-3-oxide-1 -oxyl) [15] and $\left[\mathrm{Mn}_{6} \mathrm{O}_{2}\left(\mathrm{O}_{2} \mathrm{CCMe}_{3}\right)_{10}\left(\mathrm{HO}_{2} \mathrm{CCMe}_{3}\right)_{2}\right.$ (bpy)] (bpy $=4,4^{\prime}$-bipyridine) [16].

\section{Conclusions}

We reported the syntheses and the crystal structures of compounds $\left(\mathbf{1} \cdot 2.5 \mathrm{H}_{2} \mathrm{O}\right)_{\infty}$ and $2 \cdot 2 \mathrm{MeCN}$, which are based on the well-known $\left[\mathrm{Mn}_{6}\left(\mu_{4}-\mathrm{O}\right)_{2}\right]^{10+}$ structural core. Both compounds were prepared serendipitously in our 


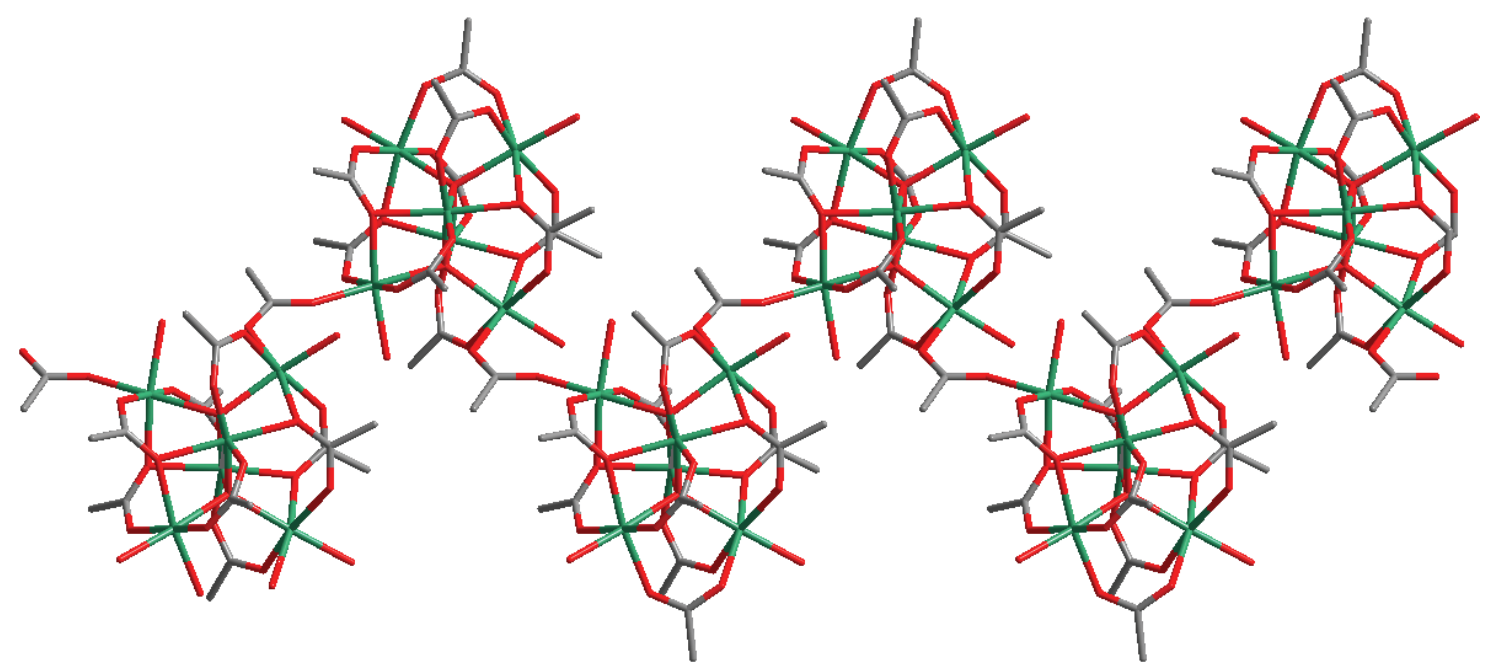

FIGURE 2: Wireframe representation of the zigzag chain of $(\mathbf{1})_{\infty}$ viewed along $a$-axis. $\mathrm{Mn}$, green; $\mathrm{O}$, red; $\mathrm{C}$, grey. $\mathrm{H}$ atoms are omitted for clarity.

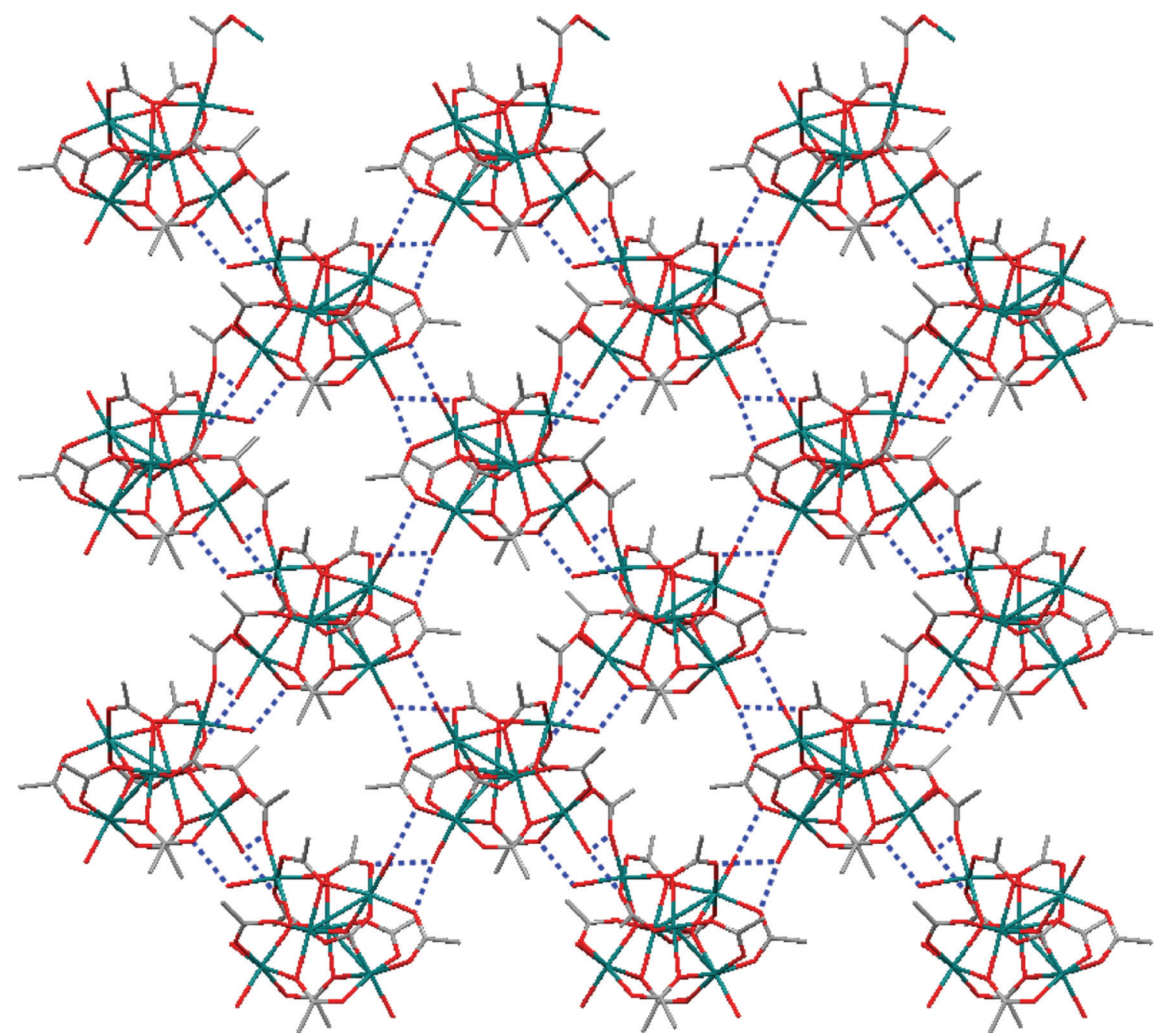

Figure 3: Wireframe representation of the layer formed by interchain hydrogen bonds in $(\mathbf{1})_{\infty}$. The hydrogen bonds are shown as dotted blue lines. Mn, green; $\mathrm{O}$, red; $\mathrm{C}$, grey. $\mathrm{H}$ atoms are omitted for clarity. 


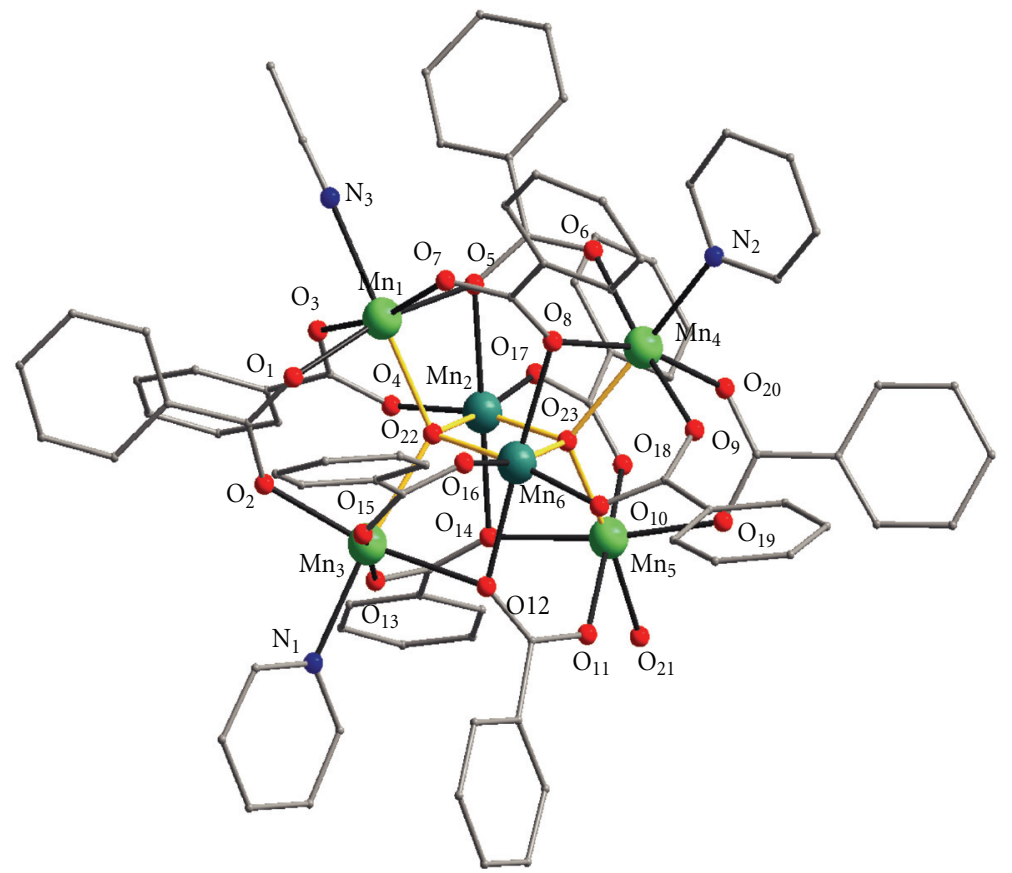

FIGURe 4: A partially labeled plot of 2 . The yellow lines emphasize the $\left[\mathrm{Mn}_{4}{ }^{\mathrm{II}} \mathrm{Mn}_{2}{ }^{\mathrm{III}}\left(\mu_{4}-\mathrm{O}\right)_{2}\right]^{10+}$ core. Color code: $\mathrm{Mn}^{\mathrm{II}}$, green; $\mathrm{Mn}{ }^{\mathrm{III}}$, dark green; $\mathrm{O}$, red; $\mathrm{N}$, blue; $\mathrm{C}$, grey. $\mathrm{H}$ atoms are omitted for clarity.

attempt to prepare polymeric species consisting of polynuclear $\mathrm{Mn}$ clusters linked through $3 \mathrm{hmpH}$. Compound $\left(\mathbf{1} \cdot 2.5 \mathrm{H}_{2} \mathrm{O}\right)_{\infty}$ features a zigzag chain structure formed by $\left[\mathrm{Mn}_{6}\left(\mu_{4}-\mathrm{O}\right)_{2}\left(\mathrm{O}_{2} \mathrm{CMe}\right)_{10}\left(\mathrm{H}_{2} \mathrm{O}\right)_{4}\right]$ clusters linked via bridging acetate ligands. This compound joins a family of coordination polymers based on the $\left[\mathrm{Mn}_{6}\left(\mu_{4}-\mathrm{O}\right)_{2}\right]^{10+}$ unit, which numbers only a few members. Furthermore, compound $2 \cdot 2 \mathrm{MeCN}$ represents a new addition in the growing family of $\mathrm{Mn}_{6}$-benzoate clusters. Further work may involve replacement of the terminal solvent molecules in $\left(\mathbf{1} \cdot 2.5 \mathrm{H}_{2} \mathrm{O}\right)_{\infty}$ or $2 \cdot 2 \mathrm{MeCN}$ by various bridging polytopic ligands, in order to isolate higher dimensionality (2D, 3D) polymers. Multidimensional coordination polymers consisting of oligonuclear Mn clusters would be potential candidates for various applications including gas storage and catalysis.

\section{Acknowledgments}

The authors thank the Cyprus Research Promotion Foundation (Grant: $\Delta \mathrm{I} \Delta \mathrm{AKT} \Omega \mathrm{P} / \Delta \mathrm{I} \Sigma \mathrm{EK} / 0308 / 22$ ), for financial support of this research. Crystallographic data in CIF format have been deposited at the Cambridge Crystallographic Data Centre with CCDC no. $767225\left[\left(\mathbf{1} \cdot 2.5 \mathrm{H}_{2} \mathrm{O}\right)_{\infty}\right]$ and $767226(2 \cdot 2 \mathrm{MeCN})$. Copies of this information can be obtained free of charge on application to CCDC, 12 Union Road, Cambridge CB2 1EZ, UK (fax: +44-1223-336033; e-mail: deposit@ccdc.cam.ac.uk). This work is dedicated to Professor Nick Hadjiliadis in recognition of his great contribution for the advancement of Bioinorganic and Inorganic Chemistry, both in Greece and internationally, and for his retirement

\section{References}

[1] R. H. Holm, P. Kennepohl, and E. I. Solomon, "Structural and functional aspects of metal sites in biology," Chemical Reviews, vol. 96, no. 7, pp. 2239-2314, 1996.

[2] R. Bagai and G. Christou, "The Drosophila of single-molecule magnetism: $\left[\mathrm{Mn}_{12} \mathrm{O}_{12}\left(\mathrm{O}_{2} \mathrm{CR}\right)_{16}\left(\mathrm{H}_{2} \mathrm{O}\right)_{4}\right]$ ], Chemical Society Reviews, vol. 38, no. 4, pp. 1011-1026, 2009.

[3] S. Mukhopadhyay, S. K. Mandal, S. Bhaduri, and W. H. Armstrong, "Manganese clusters with relevance to photosystem II," Chemical Reviews, vol. 104, no. 9, pp. 3981-4026, 2004.

[4] J. Barber, "Photosynthetic energy conversion: natural and artificial," Chemical Society Reviews, vol. 38, no. 1, pp. 185196, 2009.

[5] A. Mishra, W. Wernsdorfer, K. A. Abboud, and G. Christou, "The first high oxidation state manganese-calcium cluster: relevance to the water oxidizing complex of photosynthesis," Chemical Communications, no. 1, pp. 54-56, 2005.

[6] W. Ruttinger and G. C. Dismukes, "Synthetic water-oxidation catalysts for artificial photosynthetic water oxidation," Chemical Reviews, vol. 97, no. 1, pp. 1-24, 1997.

[7] R. Brimblecombe, G. F. Swiegers, G. C. Dismukes, and L. Spiccia, "Sustained water oxidation photocatalysis by a bioinspired manganese cluster," Angewandte Chemie International Edition, vol. 47, no. 38, pp. 7335-7338, 2008.

[8] A. J. Wu, J. E. Penner-Hahn, and V. L. Pecoraro, "Structural, spectroscopic, and reactivity models for the manganese catalases," Chemical Reviews, vol. 104, no. 2, pp. 903-938, 2004.

[9] J. Kim and H. Cho, "Reductive coupling of trinuclear $\left[\mathrm{Mn}^{\mathrm{II}} \mathrm{Mn}^{\mathrm{III}} \mathrm{O}\right]$ core to form hexanuclear $\left[\mathrm{Mn}_{4}^{\mathrm{II}} \mathrm{Mn}_{2}^{\mathrm{III}} \mathrm{O}_{2}\right]$ cluster," Inorganic Chemistry Communications, vol. 7, no. 1, pp. 122-124, 2004.

[10] C. Benelli, M. Murrie, S. Parsons, and R. E. P. Winpenny, "Synthesis, structural and magnetic characterisation of a new 
Mn-Gd pivalate: preparation from a pre-formed hexanuclear cluster," Dalton Transactions, no. 23, pp. 4125-4126, 1999.

[11] R. Manchanda, G. W. Brudvig, and R. H. Crabtree, "Highvalent oxomanganese clusters: structural and mechanistic work relevant to the oxygen-evolving center in photosystem II," Coordination Chemistry Reviews, vol. 144, pp. 1-38, 1995.

[12] T. C. Stamatatos, D. Foguet-Albiol, S. P. Perlepes, et al., "4-(hydroxymethyl)pyridine and pyrimidine in manganese benzoate chemistry: preparation and characterization of hexanuclear clusters featuring the $\left\{\mathrm{Mn}_{4}^{\mathrm{II}} \mathrm{Mn}_{2}^{\mathrm{III}}\left(\mu_{4}-\mathrm{O}\right)_{2}\right\}^{10+}$ core," Polyhedron, vol. 25, no. 8, pp. 1737-1746, 2006.

[13] A. R. Schake, J. B. Vincent, Q. Li, et al., "Preparation, structure, and magnetochemistry of hexanuclear manganese oxide complexes: chemically and thermally induced aggregation of $\mathrm{Mn}_{3} \mathrm{O}\left(\mathrm{O}_{2} \mathrm{CPh}\right)_{6}(\mathrm{py})_{2}\left(\mathrm{H}_{2} \mathrm{O}\right)$ forming products containing the $\left[\mathrm{Mn}_{6} \mathrm{O}_{2}\right]^{10+}$ core," Inorganic Chemistry, vol. 28, no. 10, pp. 1915-1923, 1989.

[14] C.-B. Ma, M.-Q. Hu, H. Chen, C.-N. Chen, and Q.-T. Liu, "Aggregation of hexanuclear, mixed-valence manganese oxide clusters linked by propionato ligands to form a onedimensional polymer $\left[\mathrm{Mn}_{6} \mathrm{O}_{2}\left(\mathrm{O}_{2} \mathrm{CEt}\right)_{10}\left(\mathrm{H}_{2} \mathrm{O}_{4}\right)\right]_{\mathrm{n}}$," European Journal of Inorganic Chemistry, no. 33, pp. 5274-5280, 2008.

[15] V. Ovcharenko, E. Fursova, G. Romanenko, and V. Ikorskii, "Synthesis and structure of heterospin compounds based on the $\left[\mathrm{Mn}_{6} \mathrm{O}_{2}\right.$ piv $\left._{10}\right]$-cluster unit and nitroxide," Inorganic Chemistry, vol. 43, no. 11, pp. 3332-3334, 2004.

[16] K. Nakata, H. Miyasaka, K. Sugimoto, T. Ishii, K.-I. Sugiura, and M. Yamashita, "Construction of a one-dimensional chain composed of $\mathrm{Mn}_{6}$ clusters and 4,4'-bipyridine linkers: the first step for creation of "nano-dots-wires"”, Chemistry Letters, no. 7, pp. 658-659, 2002.

[17] J. W. Choi, J. J. Park, M. Park, D. Y. Moon, and M. S. Lah, "A 2D layered metal-organic framework constructed by using a hexanuclear manganese metallamacrocycle as a supramolecular building block," European Journal of Inorganic Chemistry, no. 35, pp. 5465-5470, 2008.

[18] J. B. Vincent, H.-R. Chang, K. Folting, J. C. Huffman, G. Christou, and D. N. Hendrickson, "Preparation and physical properties of trinuclear oxo-centered manganese complexes of the general formulation $\left[\mathrm{Mn}_{3} \mathrm{O}\left(\mathrm{O}_{2} \mathrm{CR}\right)_{6} \mathrm{~L}_{3}\right]^{0,+}$ $(\mathrm{R}=\mathrm{Me}$ or $\mathrm{Ph} ; \mathrm{L}=\mathrm{a}$ neutral donor group $)$ and the crystal structures of $\left[\mathrm{Mn}_{3} \mathrm{O}\left(\mathrm{O}_{2} \mathrm{CMe}\right)_{6}(\text { pyr })_{3}\right]$ (pyr) and $\left[\mathrm{Mn}_{3} \mathrm{O}\left(\mathrm{O}_{2} \mathrm{CPh}\right)_{6}(\mathrm{pyr})_{2}\left(\mathrm{H}_{2} \mathrm{O}\right)\right] \cdot 0.5 \mathrm{MeCN}$," Journal of the American Chemical Society, vol. 109, no. 19, pp. 5703-5711, 1987.

[19] Oxford Diffraction, CrysAlis CCD and CrysAlis RED, Version 1.171.32.15, Oxford Diffraction Ltd, Abingdon, Oxford, UK, 2008.

[20] A. Altomare, G. Cascarano, C. Giacovazzo, et al., "SIR92-a program for automatic solution of crystal structures by direct methods," Journal of Applied Crystallography, vol. 27, p. 435, 1994.

[21] G. M. Sheldrick, SHELXL97-A Program for the Refinement of Crystal Structure, University of Göttingen, Göttingen, Germany.

[22] L. J. Farrugia, "WinGX suite for small-molecule single-crystal crystallography," Journal of Applied Crystallography, vol. 32, no. 4, pp. 837-838, 1999.

[23] K. Brandenburg, DIAMOND. Version 3.1d, Crystal Impact GbR, Bonn, Germany, 2006.

[24] C. F. Macrae, P. R. Edgington, P. McCabe, et al., "Mercury: visualization and analysis of crystal structures," Journal of Applied Crystallography, vol. 39, no. 3, pp. 453-457, 2006.
[25] S. Zartilas, E. E. Moushi, V. Nastopoulos, A. K. Boudalis, and A. J. Tasiopoulos, "Two new coordination polymers containing the triangular $\left[\mathrm{Mn}_{3} \mathrm{O}\left(\mathrm{O}_{2} \mathrm{CR}\right)_{6}\right]^{0 /+}$, , Inorganica Chimica Acta, vol. 361, no. 14-15, pp. 4100-4106, 2008.

[26] X. Bu, N. Zheng, and P. Feng, "Tetrahedral chalcogenide clusters and open frameworks," Chemistry: A European Journal, vol. 10, no. 14, pp. 3356-3362, 2004. 


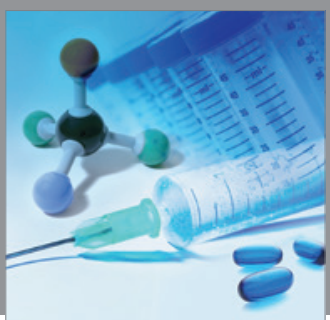

International Journal of

Medicinal Chemistry

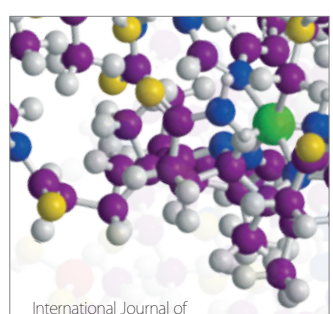

Carbohydrate Chemistry

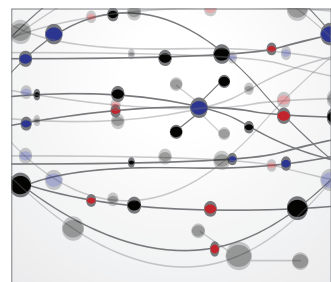

The Scientific World Journal
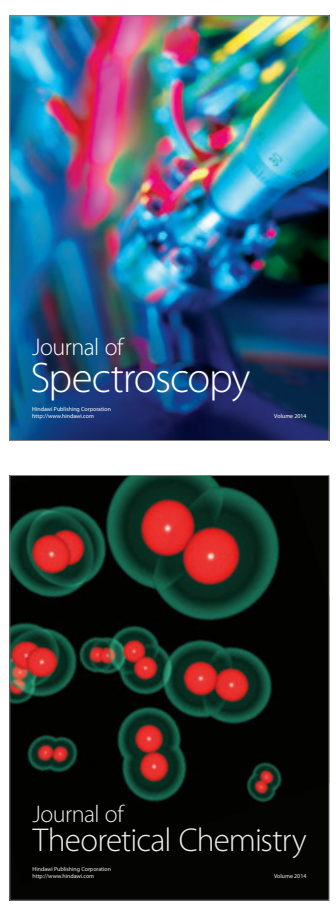
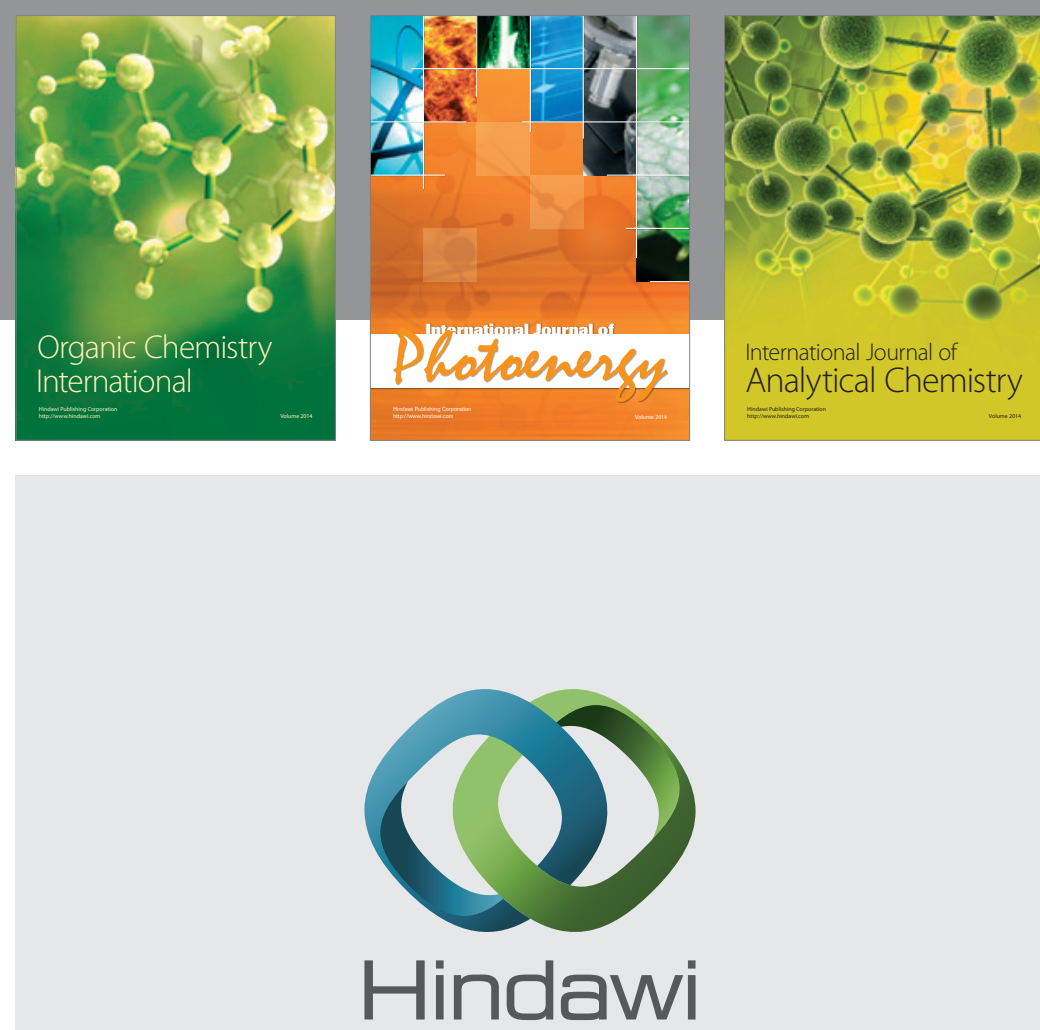

Submit your manuscripts at

http://www.hindawi.com
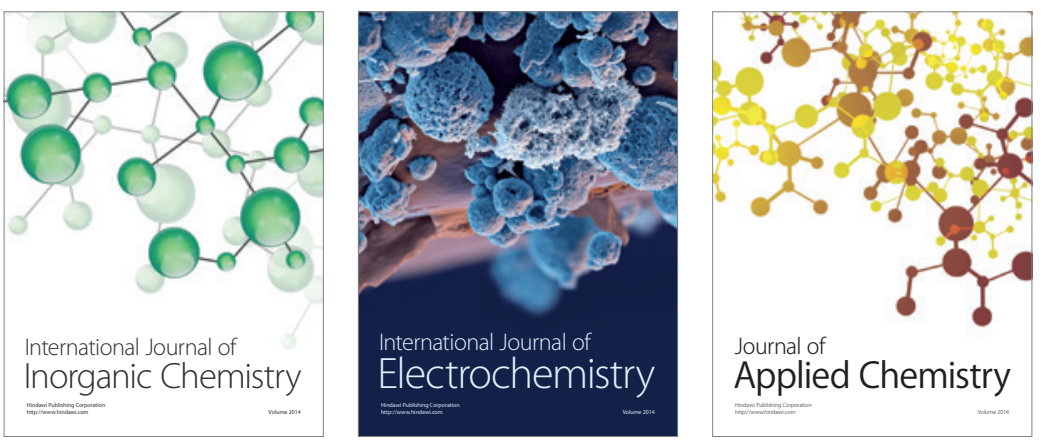

Journal of

Applied Chemistry
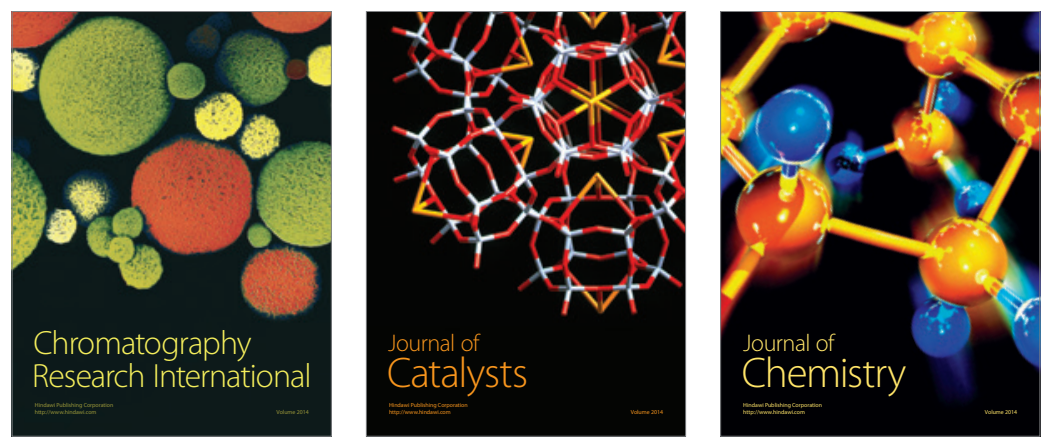
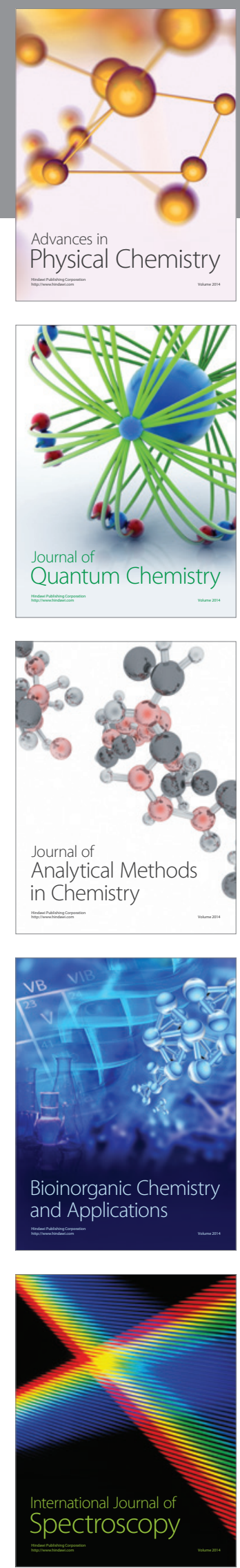